\title{
CPEC, GOVERNANCE, AND CHINA'S BELT AND ROAD IN SOUTH ASIA
}

\section{The path of most resistance?}

\author{
Marc Lanteigne ${ }^{1}$
}

\section{Introduction: CPEC and China's South Asian strategies}

Although China's Belt and Road Initiative (yidai yilu一带一路) (BRI) trade policies have frequently been presented by Beijing as primarily an economic exercise, designed to more effectively link China with key cross-regional markets, both political and security concerns have never hovered far from the BRI in several ways. At the same time, Belt and Road agreements and investments have also had effects on various levels of local governance among BRI partners. Few examples of these effects have more effectively been demonstrated than in South Asia, where reactions to these emerging trade routes have been especially polarizing. While this region acts as a key land bridge to other parts of Asia, just as crucial for the BRI has been the Indian Ocean, which is by far the most important link in the '21st Century Maritime Silk Road' which Beijing wishes to create, since the waterway connects the Chinese economy to regions, especially Africa and the Middle East, with which Beijing is especially anxious to deepen engagement. Moreover, China is also seeking to expand its economic presence within the Indian Ocean area itself, raising questions about potential regional rivalries given India's traditional dominance of that region.

Several South Asian / Indian Ocean governments have engaged China in the wake of its BRI overtures. By far, however, the most prominent actor in the South Asian 'wing' of the Belt and Road has been Pakistan, a venerable Chinese ally and political partner since well before the government of Xi Jinping introduced the BRI in 2013. Islamabad has been the recipient of arguably the most formal and intricate element of the Initiative, namely the ChinaPakistan Economic Corridor (ZhongBa jingji zoulang中巴经济走廊) or CPEC (Ministry of Planning - Pakistan 2021). This development blueprint was founded in 2013, a result of a proposal by Chinese Premier Li Keqiang, as a constellation of development and infrastructure projects designed to further develop the Pakistani economy and consolidate the country's bilateral economic ties with Beijing (Reuters/SCMP 23 May 2013). Central to the success of this enterprise was the development and expansion of the Pakistani port of Gwadar to act as a transit hub for Chinese maritime shipping and a nexus for Chinese trade further inland, to South and Central Asia. Both China and Pakistan frame CPEC as an exercise in mutual economic 
development. Yet in many ways, CPEC is also a microcosm of the Belt and Road as a whole, reflecting the challenges of developing infrastructure and the relevant financing, in addition to having to integrate the economic aspects of the BRI with local and regional politics and strategies, effecting various levels of governance within Pakistan and creating a challenge to the already-fragile political structures which were created after the return to civilian government in the country in 2008.

At present, it remains too soon to judge the success of CPEC, as many of its components have been beset with delays, political pushback within various administrative levels in Pakistan and ongoing security challenges. The economic and health effects of the post-2020 global pandemic on the region and on Sino-Pakistan cooperation are yet to be determined. However, in addition to occasional strains on the Sino-Pakistan relationship since CPEC's creation, the plan's evolution has prompted concerns about domestic political directions in Pakistan. However, even at this (indeterminate) stage, it can be argued that the Corridor plan has greatly affected the economic relationship between China and Pakistan and as will be argued, has also added an additional layer to existing regional diplomacy and security concerns, especially in the case of Pakistan's main adversary, India.

CPEC can also be considered a difficult learning experience for Beijing, given that the BRI in Pakistan has also shone an uncomfortable spotlight on the limitations of the Belt and Road in separating developmental from governance and security concerns. However, CPEC's progress thus far should also be evaluated in regard to its potential effects on pluralism in Pakistan, and whether the Corridor may be exacerbating political and security stresses within the country which may open the door to greater risks of autocratization, defined in this sense as a process of regime change towards greater autocracy (Cassani and Tomini 2020). By placing such a great emphasis on the success of the CPEC process, Islamabad may be opening the door to greater risks of both political schisms and regional rivalries within Pakistan, as well as forcing questions about the internal security of the country as it continues to struggle with insurgencies and terrorism in the country's peripheries.

\section{The inception, and uneven trajectory, of the BRI in South Asia}

During the two initial speeches by President Xi which inaugurated China's Belt and Road projects, the first outlining the 'belt' as a series of land routes connecting Northeast Asia to Europe via Russia and Eurasia, and the second detailing the 21st Century Maritime Silk Road, South Asia was not directly mentioned, but it became obvious that the region was going to be affected very much in its early stages by the BRI. President Xi first described the 'belt', during his speech in Astana, Kazakhstan, as working its way through Central Asia, while the subsequent speech on the Maritime Silk Road was given in Jakarta and featured the Association of Southeast Asian Nations (ASEAN) as the main case example (Xi 2014).

Yet, since both Central and Southeast Asia are adjacent to South Asia, it was clear that for Beijing to be successful in the development of both facets of the BRI, the Indian Ocean region would be needed by China as a vital conduit to numerous overseas markets. Moreover, for the BRI in that part of the world to be successful, Beijing would not only need to develop many partnerships with countries in the region, but also multiple points of access for Chinese trade, especially given concerns about both rival sea powers India and the United States (Kaplan 2011, 277-93). Before turning to the specific case study of Pakistan, it is necessary to observe how the BRI has developed in the overall South Asia / Indian Ocean milieu, given that while Islamabad remains the anchor of the BRI in the region, the Belt and Road has been making 
regional gains elsewhere with the possibility Pakistan may evolve into a core of the initiative's expanded Indian Ocean network.

India, a strategic rival to China, is an ideal starting point as well as the antithesis to the Pakistani case. New Delhi, an avowed non-participant in the BRI, dominates South Asia not only geographically but also due to its economy and its military power. Sino-Indian trade has traditionally been robust, and the two states also participate in larger economic and strategic regimes, including the Group of Twenty, the 'BRICS' configuration (the economic cooperation between the large emerging economies of Brazil, China, India, Russia and South Africa), the Shanghai Cooperation Organisation (SCO), and the Beijing-led Asian Infrastructure Investment Bank (AIIB) (Cooper and Farooq 2016). China is also an observer in the South Asian Association for Regional Cooperation (SAARC), which counts India and Pakistan as its largest members. Politically, however, the Sino-Indian bilateral relationship has a far different shape, starting with the two powers being regional adversaries who fought a frontier conflict in 1962 which resulted in China's annexation of the Aksai Chin region. The two countries continue to maintain a tense watch over their disputed mutual border which has occasionally bubbled over into violence in the succeeding decades. China's close relations with Pakistan, starting with a friendship agreement in 1956 and continuing with closer economic and security cooperation (Khan 1961), further elevated Beijing as a security challenge in the eyes of the Indian government.

What has changed due to the BRI are emerging Indian concerns about Chinese economic encirclement via the various land and sea elements of the Belt and Road, as well as the possibility that the BRI in South Asia could evolve into a 'Trojan Horse' to reduce India's own power in the region. Thus, New Delhi has kept out of the Initiative, reflecting the ongoing disconnect between the economic and strategic dimensions of the Sino-Indian relationship, a situation which commentators have referred to as the 'four C' problem ('conflict, competition, cooperation and containment') (Sachdeva 2018; Joshi 2018). While both China and India are large economies with burgeoning markets, Prime Minister Narendra Modi has declined to sign a Belt and Road cooperation agreement with Beijing.

Decades of mistrust between Beijing and New Delhi, including over the status of their border and Beijing's robust, 'all-weather' (quantianhou 全天候) relationship with Pakistan (Mu 2018), have been more recently compounded by concerns in New Delhi about an increasing Chinese security presence throughout the region. This stance not only reflects worries about expanded Chinese economic diplomacy in many parts of South Asia and the Indian Ocean, including via the BRI, but also the enhancement of Chinese military land and sea-power which may challenge traditional Indian hegemony in these regions. In 2015, Beijing announced its intention to build a 'logistical support facility' (baozhang sheshi 保障设施) in Djibouti, the first such Chinese overseas base (Cabestan 2020). Although it has been described by Chinese authorities as required for resupply and support for multilateral missions, such as counter-piracy operations and peacekeeping, the placement of the facilities on the Red Sea and in a position to oversee North Africa, the Middle East and the Arabian Sea, has further underscored the importance of the Indian Ocean to Chinese security interests (including economic security via the BRI).

The most pressing concern for India vis-à-vis a China security threat has been their mutual disputed border. The Doklam Incident in mid-2017, when Chinese and Indian soldiers were involved in a tense faceoff on the tri-border area with Bhutan, starkly illustrated the fact that although there remains a cold peace on the Line of Actual Control (LAC), meaning the frontier between the two powers, an agreement on the demarcation of the boundary in the politically fragile Kashmir region remains elusive (Panda 2017). 
A brief but violent skirmish in June 2020 between Chinese and Indian soldiers in the Galwan River Valley, in the Aksai Chin area resulted in at least twenty fatalities from the Indian side and an unspecified number of deaths and injuries of Chinese military personnel. Despite the fact that no firearms were present during the fighting, rocks, batons and other improvised mêlée weapons were used, while some deaths were reportedly caused by falls from great heights. This was the first time such an incident of such magnitude took place along the LAC since 1975. The political aftershocks, and Indian outcry after the incident, further degraded the diplomatic situation between the two governments (Peri et al. 2020; Goldman 2020; Singh 2021). The Modi administration has thus been forced to walk a fine line between moving to better check Chinese security interests in South Asia, and maintaining key Indian economic links with Chinese markets despite the souring political relationship, especially in the wake of Indian public outcry over the Doklam and Galwan incidents.

Elsewhere in the region, medium powers Bangladesh and Myanmar have been much more open to BRI engagement, and both countries have been central to Beijing's interests in developing a stronger presence on the Indian Ocean coast. The BRI has gained support in Bangladesh, not only because of Chinese economic power but also because the initiative opens the possibility of developing Beijing ties as a counterweight to India. China, in turn, has expressed interest in engaging Bangladesh through various development programmes including the BangladeshChina-India-Myanmar (BCIM) corridor (Mardell 2020, Saimum 2020). China has retained its dominant role in Myanmar regional relations, with Yangon as a supporter of the BRI despite Myanmar's own security concerns with Beijing and local Myanmar concerns about the financial viability of the China-backed Kyaukphyu port project (Lanteigne 2019; Reed 2020; Ryack 2020). Small states Bhutan and Nepal have found themselves often caught between two giants, as China and India have accelerated their geopolitical rivalry in the Himalayas. The Doklam Incident, for example, underscored Bhutan's tenuous strategic situation, and that state has also eschewed participation in the BRI. Nepal, by contrast, has been more receptive to Chinese investments, especially since the 2015 earthquakes, as Beijing was a major provider of aid and support to the Nepalese government during that crisis (Parashar 2019; Vater and Siegel 2019).

To the south, Sri Lanka has been frequently presented in the West, especially the United States, as a Belt and Road cautionary tale about the dangers of a too-close embrace of the BRI in the form of Chinese 'debt traps'. However, in reality the island nation represented a (rare) case of an asset transfer to Beijing, in this case the port facilities at Hambantota, due to non-payment of debts. Despite being commonly cited as an example of alleged Chinese predatory loan practices, the Sri Lankan case in reality was a result of overall poor financial management of which China was only a minor player in Colombo's overall debt crises (Kratz et al. 2019; Jones and Hamieri 2020; Hundlani and Kannangara 2020). However, Chinese economic dominance in Sri Lanka continues to be a concern not only for detractors within the country but also for India. In December 2020, for example, it was announced that a Chinese firm would build a US $\$ 300$ million tyre manufacturing plant near Hambantota, which would make the first major BRI Chinese investment in local manufacturing. Moreover, there remain concerns that Hambantota itself could in the future be used not only to service civilian ships but potentially Chinese naval vessels as well. This despite the fact that plans were announced in mid-2018 to use the port for the Sri Lankan navy, not Chinese military vessels (Agence France-Presse / South China Morning Post 2020; Reuters 2 January 2018).

Finally, the island economies of the Maldives, Mauritius and Seychelles have become the focus of Beijing's local 'small state' diplomacy within the Belt and Road frameworks (MacDougall and Taneja 2020; Robinson 2015, 88-93). Chinese debts in the Maldives related to the BRI, including the centrepiece Sinamale Bridge project completed in 2018, became the source of intense political concern in the latter's government. The situation is less confrontational in 
Mauritius, however, as that state celebrated the activation of a bilateral free trade agreement (FTA), the first China has penned with an African state, in January 2021. China has expressed hopes that this deal will be a test for future agreements in Africa, as Chinese economic diplomacy on the continent continues to accelerate at a rapid pace (Ethirajan 2020; Mundy and Hille 2019; Nyabiage 2021). The government of the Seychelles has also been a supporter of the BRI, and the island state's willingness to foster closer economic cooperation with Beijing was further affirmed during a visit by Chinese Foreign Minister Wang Yi in the first month of 2021, with meetings which included pledges of further Chinese support in the areas of energy, tourism and transportation, as well as health in the wake of the global pandemic which began the previous year. Seychelles also received the distinction of being the first African state to distribute the China-made vaccine for the Covid-19 coronavirus (CGTN 2021; AFP / SCMP 10 January 2021).

Thus, Beijing has made significant gains in its 'ink spot' strategy in developing the BRI in South Asia, as well as addressing the potential for pushback by India. All of these regional successes, however, remain modest compared to the commitments which the Chinese government made to Pakistan via the CPEC process. The potential successes of CPEC would be seen by Beijing as a significant vote of confidence for the greater Belt and Road, which has now become the centrepiece of Chinese foreign policy and cross-regional diplomacy.

\section{The fundamentals of CPEC and Pakistan's responses}

The economic relationship between China and Pakistan, despite weathering numerous political storms, has remained robust since the Belt and Road was initiated, with total trade in 2019 measured at just under US $\$ 18$ billion (down from a 2017 peak of US $\$ 20.1$ billion). The two countries had signed a free trade agreement in 2006, following up that pact with a similar agreement of liberalization of services three years later and with an updated FTA in 2019. By 2011, China had become Pakistan's largest trading partner (MFA China 2021; Shah et al. 2020; Kundi 2020), and given the strength of bilateral cooperation, as well as Chinese strategic interests in the Indian Ocean, it was not surprising that Islamabad would be amongst the first, and the largest, of BRI-related initiatives.

As the name suggests, the core of CPEC was the planned creation of infrastructure which would connect the far western Chinese territory of Xinjiang with international markets via the southern Pakistan coast, and specifically that country's port city of Gwadar. However, in addition to communication and transportation (highways and railways), CPEC is also envisioned as a platform for bilateral cooperation with other sectors including agriculture, energy, finance, health, human development, information technology and tourism. Various China-backed Special Economic Zones (SEZs) were also established in various Pakistani provinces, including Balochistan, Punjab, and Sindh, as well as in the Federally Administered Tribal Areas (FATA), which in 2018 were incorporated into the province of Khyber Pakhtunkhwa, and Pakistan's holdings in Kashmir, referred to in Pakistan itself as Azad Jammu and Kashmir, but in India as Pakistan-occupied Kashmir (PoK). Economic security concerns were also incorporated into CPEC thinking, as illustrated by the additional focus on counter-poverty measures as well as maintaining border stability and associated human security and stability in the frontier regions, especially given the often-precarious situation in Kashmir (Government of Pakistan 2020; Syed 2020; Chen and Zhang 2016).

What made the CPEC idea distinct, however, was that its projects would loop together aspects of both the land based 'belt' and the maritime 'road', via what was referred to as a ' $1+4$ ' planning structure, with the 'one' being the actual economic corridor, accompanied by four 
sets of projects: energy, industrial cooperation, infrastructure, and the Port of Gwadar development initiatives (Wing et al. 2020). As one Chinese academic paper argued, there were many 'early harvest' (zaoqi shouhuo早期收获) successes within CPEC projects, including the expansion of Gwadar, as specific energy and transportation infrastructure as well as in agriculture and services, but the Corridor is far from complete (Tao and $\mathrm{Gu} 2019$ ). There have also been considerable problems faced by both Beijing and Islamabad which have slowed progress. These matters include internal political disputes within Pakistan, concerns about Pakistani debts in relation to the projects, and looming security concerns threatening the project, as well as whether the state of the global economy post-pandemic will adversely affect global trade patterns at least in the near-term.

The original budget for CPEC was estimated at US $\$ 45$ billion after its original inception, but that figure was later raised upwards to over US $\$ 60$ billion. Nonetheless, a September 2020 critique by Andrew Small suggested that the latter figure was over-optimistic given that many projects were scaled back between 2015-18, with pandemic-related effects seen as likely adversely affecting the Corridor's bottom line as well (Ul Hassan 2020, Small 2020). Beyond the potential developmental benefits for Pakistan, Islamabad also sees advantages to the Corridor in an improved counterbalance of diplomatic pressures from India, as well as the United States. Despite longstanding diplomatic ties between Islamabad and Washington, American influence in Pakistan relative to China was thought to be eroding, especially during the isolationist US presidency of Donald Trump and its interests in severely reducing financial support for the Pakistani military (Shah 2017; Chacko 2018). Thus, CPEC was also a product of a perceived window of opportunity for the $\mathrm{Xi}$ government to further improve its diplomatic and strategic standing in South Asia. In addition to the economic dimensions of CPEC, the Corridor also opened up opportunities for closer cooperation between the Chinese and Pakistani militaries, including reportedly in the areas of joint weapons development and satellite launches (AbiHabib 2018). However, considering the still-strong role of the military within Pakistani politics, the domestic political effects of this partnership do carry risks involving power-sharing between Pakistan's civilian government and its armed forces.

All roads, figuratively and at times literally, within CPEC lead in some way to Gwadar, and it is this municipality which continues to be a barometer of CPEC's overall progress. Gwadar is a coastal town on the Arabian Sea with an estimated population of 85,000 , but with ambitious government plans announced to increase that number to two million by 2050 (Aamir 2020). The area had been an area of interest for China that long-predated the inception of the Belt and Road, but once the BRI had begun to expand in South Asia, the region was to be incorporated into China's Maritime Silk Road interests in the Indian Ocean, as well as Beijing's strategy of developing friendly ports around the area in anticipation of increased Chinese sea traffic. This strategy has frequently been referred to as a 'string of pearls' (zhenzhu lian珍珠链) approach on Beijing's part, and many of China's BRI arrangements in and around the Indian Ocean could also have emerging strategic value, much to the chagrin of both India and the United States (MacDonald et al. 2004; Miller 2017, 167-8).

Gwadar and the surrounding areas were purchased by the Pakistani government in 1958 from the Sultanate of Oman, which had overseen the region for approximately two centuries. Islamabad had high expectations of developing an expanded port facility there, while Gwadar's location, not only close to Iran but also to the oil emirates and the fossil fuel-rich Persian Gulf and Strait of Hormuz, caught the attention of China by the late 1990s as Beijing was seeking to develop alternative energy routes to the Malacca Straits in Southeast Asia (Khetran 2014; Khan 2018; Chongyang Institute for Financial Studies of Renmin University 2016; Kalim and Syed 2020). At the turn of this century, the Chinese government was seeking to develop 
stronger maritime capabilities but was also concerned with the 'Malacca dilemma' (Lanteigne 2008), namely the strategic risks of having the Malacca Straits interdicted by an outside power. Even though importing fossil fuels and other goods via Gwadar was far less cost-effective than the traditional means of using the Strait and the South China Sea route, the former option was considered a vital option in case the latter was threatened. Plans by the Pakistani government to turn Gwadar into a maritime transport hub ran into logistical problems shortly after construction began in 2002, and five years later it was agreed that the contract to complete the work would be granted to the China Overseas Ports Holding Company (Zhongguo haiwai gangkou konggu youxiangongsi 中国海外港口控股有限公司). The first substantial shipment of Chinese goods to pass through Gwadar was celebrated by both governments in November 2016 (Reuters 13 November 2016; Miller 2017, 175).

As one China-based analysis detailed, the most significant effects of CPEC thus far have been the improvement of 'all-weather strategic cooperation' between the two states and the development of economic 'growth points' within Pakistan thus improving overall economic performances. In addition, CPEC was described as an invaluable model of the advantages of Belt and Road Cooperation, and so Beijing has remained dedicated to ensuring the Corridor is successful (Zhang 2019). From the viewpoint of Pakistan, however, the results have been considerably more mixed, creating political stresses within the country and exacerbating many internal political and regime tensions. After the early harvest successes of CPEC, by 2017 the various processes were beginning to slow down, and concerns were raised that growing tensions between then-Prime Minister Nawaz Sharif, a strong supporter of deepening economic ties with China, and the Pakistani military might lead to a political crisis.

As the aforementioned 2020 study by Andrew Small argued, Mr Sharif's dedication to the CPEC idea resulted in raised suspicions amongst military leaders about a too-close geopolitical relationship with Beijing and the potential for corruption (Small 2020, 35-40). This uncertainty subsequently plagued any further CPEC-related progress until the controversial July 2018 elections, which saw the coming to power of Imran Khan of the Pakistan Movement for Justice (Pakistan Tehrik-e-Insaf - PTI) party with the new Prime Minister continuing to support the Corridor but taking on a more balanced stance and noting that Pakistan could also stand to learn from China's previous developmental successes (Al-Jazeera 2018). Prime Minister Khan's arrival in office signalled a more nuanced, smaller-scale 'CPEC 2.0' approach which better fitted the economic realities of both China and Pakistan, but despite the planned slower approach, many of the economic and strategic issues surrounding CPEC remained.

\section{CPEC next: making the most of an uncertain future?}

While the global economic trauma during 2020 contributed to reservations about CPEC's short-term agenda, obstacles to its development from various directions had begun to appear well before the pandemic. Among these have been direct political and security concerns for Pakistan which have been affected by CPEC, demonstrating the difficulties created by trying to separate the Corridor from the strategic challenges of the region but also problems of governance and risks of greater autocratization facing Islamabad should various internal power balances be upset by the ongoing development of CPEC plans. These have included the exacerbation of political cleavages within Pakistan, including between various provinces and regions, as well as between civilian actors and the still-politically powerful Armed Forces. After the military government of General Pervez Musharraf, which seized power in 1999, gave way to civilian administrations nine years later, the Pakistan Armed Forces never strayed far from the main levers of power in the country, and under the Khan government, the Army Chief of Staff, 
General Qamar Javed Bajwa, exercises considerable influence over the country's foreign affairs, including relations with Beijing (Krishnan 2021, Shah 2020). Thus, CPEC will continue to act as a critical variable in questions of both pluralism and risks of autocratization in the country.

In analysing these concerns, it is efficacious to examine Pakistan's current strategic concerns. Various mechanisms within the CPEC process have found themselves entangled, and in many cases unwittingly, in security concerns plaguing both the north and the south of Pakistan. Chinese CPEC-related investment in Pakistani-held Kashmir has been a sore point for the Modi government since the development of the Corridor. The Line of Control (LoC), which separates Indian- and Pakistan-held Kashmir, routinely sees both sides accusing the other of ceasefire violations, with China, including local Chinese investments, being more frequently seen as an unstable additional element in Kashmir's security situation. Moreover, since the main links for CPEC's transportation projects run through Pakistan-held Kashmir, it remains in Beijing's interests to assure stability, especially with the restive Chinese territory of Xinjiang right across the border (Ramachandran 2018). The Xi government retains hopes that the successful set of CPEC economic and transportation links will also have a stabilizing effect on China's far west, but navigating Pakistan's internal politics and security risks remains a challenge for Beijing.

In keeping with traditional Chinese foreign policy views equating security with counterpoverty, the CPEC process has sought to include components in Pakistan's territory in Kashmir, including a planned SEZ at Moqpondass which would specialize in raw material processing, including metals and minerals (Ministry of Planning - Pakistan 2020; Bhat 2019). However, India's worries about the strategic impact of CPEC's investments in Kashmir, including the Moqpondass installations, were not assuaged when Prime Minister Khan began to moot suggestions in 2019 that Pakistan's territory in Kashmir, still claimed by India, could eventually be incorporated as a new province of Gilgit-Baltistan. Such a move, however, would be seen in New Delhi as not only an escalation of local tensions, but also serving Chinese economic interests, including the enhancing security of the main transport lines under CPEC (Hussein 2020; Kartha 2021; Shahid 2020b).

The security situation facing CPEC is just as precarious in southwestern Pakistan, especially in the case of Balochistan, the least developed province of the country despite being resourcerich and which includes Gwadar. Within the province, local militants and separatists, supported by Daesh/Islamic State, have staged attacks and kidnappings, with Chinese nationals also being targeted. This has prompted concerns in both Beijing and Islamabad about the potential for further attempts to destabilize CPEC projects, and these threats have served to create a rift between the country's civilian policymakers and the armed forces. In mid-2020 the Pakistani military began to push for additional legislation which would permit that body to have more direct control over CPEC projects, with the argument that military oversight would quicken the pace of the Corridor's development, given the dysfunction of the Khan administration, as well as assuring Beijing that their investments would be more secure (Findlay 2020; Shakil 2020). Critics of the move, including opposition parties in Pakistan, have expressed concerns that such a new law would considerably strengthen the overall policymaking and economic power of the military. Plans were mooted during 2020 to entirely fence in the Gwadar port facilities before local authorities reversed the decision in January of the following year under public pressure (Aamir 2021; Keegan 2021).

Local anger in Pakistan at China's economic presence in the region has not been aided by the global backlash against reports of re-education facilities in Xinjiang which have targeted the region's Uighur populations. Beijing is seeking to walk a fine line between ensuring the security of its CPEC investments, especially since the Corridor remains at the core of many of China's BRI plans, and avoiding perceptions of developing a hegemonic relationship with 
Pakistan. One solution has been for closer, targeted security cooperation between the two governments designed to protect the integrity of the CPEC process, especially in the case of the tenuous security situation in Balochistan caused by the ongoing threat by local militants (Basit 2019). The Chinese and Pakistani governments are worried about direct attacks on CPEC facilities by the Balochistan Liberation Army (BLA), a radical organization which for the past two decades has sought independence from Pakistan, and affiliated groups. Since the CPEC processes began, the BLA has also considered Chinese interests to be legitimate targets (Beg et al. 2019; Washiyama 2020; Chaudhury 2020). Islamabad is concerned that these threats, coupled with the slowdown of the Chinese economy caused by the post-2018 Sino-American trade war and the global pandemic, may temper Beijing's enthusiasm for continuing CPEC at its previous pace, and therefore the Khan government has been interested in allaying Chinese fears over the Corridor's integrity. Improved Sino-Pakistani security cooperation may address issues related to the complications of completing CPEC's main plans in a timely and safe fashion, but it is clear that the problems facing the Corridor are starting to adversely affect civilmilitary relations within Pakistan, and could create further problems for South Asia's overall stability, especially as it relates to India but also the Indian Ocean as a whole, given regional concerns about China's economic and strategic expansion and whether Pakistan may further evolve as a platform for these ambitions.

Politically, China is also having to face an often-uncertain atmosphere in Islamabad, including concerns about divisions between political actors in Pakistan, communications between government actors and their Chinese counterparts, and managing public expectations of CPEC's goals. The latter became more complicated given the economic shocks, which had begun to weaken the Khan government, caused by the start of the 2020 pandemic and subsequent depressed global economic activity (Liu 2016; Kundi 2021; Findlay and Bokhari 2021). When the project began, the Pakistani political establishment was far from united on the benefits of the Corridor, and Chinese officials were wary of numerous areas of underdevelopment in Pakistan which would hamper CPEC goals, in addition to the difficult security situation in the country. Ensuring that the benefits of CPEC are distributed as evenly as possible throughout Pakistan has also been a considerable challenge for both governments, especially since regionalism, including in Balochistan, has been a longstanding problem for many Pakistani administrations.

Moreover, there has been the omnipresent problem of corruption in Pakistani political quarters, at times creating a backlash on the CPEC process, with one notorious example being an opposition campaign in 2020 to remove the Khan government's main official overseeing CPEC operations, Asim Saleem Bajwa, a retired Lieutenant-General in the Pakistan Army, on corruption and misappropriation of funds charges. In October of that year, Mr Bajwa agreed to step down as an advisor to Prime Minister Khan, but retained his post as CPEC head (You and Zhou 2019; Ahmad et al. 2020; Shahid 2020a; The Hindu / PTI 12 October 2020). The affair further illustrated the problems that the Xi government has had in trying to keep CPEC projects free of influence by internal Pakistani affairs, and underscored the fact that despite the ongoing potential of the Corridor, its eventual success will be greatly dependent on whether a sufficient degree of political (and governmental) stability in Pakistan is maintained. However, CPEC has also revealed another facet of the precarious political balance between the civilian government and the military within Pakistan, and with so much investment at stake, there is the question of whether the push to stabilize Pakistan's economic and security situation so that CPEC can conclude will throw open the door to more visible power struggles and threats to the current system of governance in the form of autocratization risks.

CPEC was crafted to be an economic conduit between China and Pakistan, as well as the 'jewel in the crown' amongst various Belt and Road projects in the South Asia / Indian Ocean 
regions. Yet, ultimately the Corridor could not escape the development of both a political and a strategic identity, and its building blocks have started to have significant effects on the SinoPakistani relationship as well as matters of governance, including effects on civilian-military relations, pluralism, and the integrity of the current system of civilian government, within Pakistan itself. The projects which comprise CPEC have experienced periods of both optimism and pessimism since 2013. The after-effects of the global pandemic, political instabilities within Pakistan, and the cooled relationship between Beijing and New Delhi are all variables which will now determine the near future of CPEC's evolution. The end point of this branch of the Belt and Road may not be easy to predict at present, but it can be argued that its progress has already had a significant effect on questions of governance, the questions of security and stability, and the risks of autocratization in Pakistan, as well as the political and security question throughout South Asia.

\section{Note}

1 The author would like to thank Lynn Gardinier, Francesca Rán Rositudóttir and Mingming Shi for their invaluable assistance in the preparation of this chapter.

\section{Bibliography}

Aamir, Adnan. (2020). 'Gwadar Port: New Dubai or Pie in the Sky?' The Interpreter, 1 May, $<$ www.lowyinstitute.org/the-interpreter/gwadar-port-new-dubai-or-pie-sky>.

Aamir, Adnan. (2021). 'Deadly IS Attack Threatens China's Belt and Road in Pakistan,' Nikkei Asia, 10 January 2021, <https://asia.nikkei.com/Spotlight/Belt-and-Road/Deadly-IS-attack-threatens-China-s-Beltand-Road-in-Pakistan>.

Abi-Habib, Maria. (2018). 'China's “Belt and Road” Plan in Pakistan Takes a Military Turn,' New York Times, 19 December 2018.

Agence France-Presse / South China Morning Post. (2020). 'Belt and Road Initiative: China Builds US\$300m Factory Near Sri Lanka Port,' 8 December, <www.scmp.com/news/article/3113076/ belt-and-road-initiative-china-builds-us $300 \mathrm{~m}$-factory-near-sri-lanka-port $>$.

Agence France-Presse / South China Morning Post. (2021). 'Coronavirus: Seychelles Becomes First African Nation to Start Vaccinating Population, Using Chinese Drug,' 10 January, <www.scmp.com/news/ world/africa/article/3117144/coronavirus-seychelles-becomes-first-african-nation-start>.

Ahmad, Riaz, Hong, Mi and Lloyd, W. Fernald. (2020). 'Revisiting the Potential Security Threats Linked with the China-Pakistan Economic Corridor (CPEC),' Journal of the International Council for Small Business 1(1): 64-80.

Al-Jazeera. (2018). 'Imran Khan's Speech in Full', 26 July, <www.aljazeera.com/news/2018/7/26/ imran-khans-speech-in-full>.

Basit, Saira H. (2019). 'Terrorizing the CPEC: Managing Transnational Militancy in China-Pakistan Relations,' Pacific Review 32(4): 694-724.

Beg, Saadia, Tasawar, Baig and Muqarrab, Akbar. (2019). 'Analysis of the Impact of China-Pakistan Economic Corridor (CPEC) on the Insurgency in Balochistan and Options for Conflict Resolution,' Pakistan Journal of Social Sciences (PJSS) 39(2): 459-71.

Bhat, Vinayak. (2019). 'Pakistan \& China are Building an SEZ in PoK's Gilgit-Baltistan, Satellite Images Show,' The Print (India), 27 August, <https://theprint.in/world/pakistan-china-are-building-an-sezin-poks-gilgit-baltistan-satellite-images-show/282413/>.

Cabestan, Jean-Pierre. (2020). 'China's Military Base in Djibouti: A Microcosm of China's Growing Competition with the United States and New Bipolarity', Journal of Contemporary China 29(125): 731-47.

Cassani, Andrea and Luca, Tomini. (2020). 'Reversing Regimes and Concepts: from Democratization to Autocratization,' European Political Science 19: 272-87.

CGTN. (2021). 'China, Seychelles to Jointly Promote Belt and Road Construction,' 10 January, <https:// newsaf.cgtn.com/news/2021-01-10/Chinese-FM-holds-talks-with-Seychellois-counterpartWVaAX7bT1K/index.html>. 


\section{Marc Lanteigne}

Chacko, Johann. (2018). 'The US-China Cold War is Now Playing Out in Pakistan,' Quartz, 3 September, $<$ https://qz.com/india/1377225/the-us-china-cold-war-is-now-playing-out-in-pakistan/>.

Chaudhury, Dipanjan Roy. (2020). 'Balochistan \& CPEC: China's Achilles' Heel,' The Economic Times (India), 31 December 2020, <https://economictimes.indiatimes.com/news/international/worldnews/balochistan-cpec-chinas-achilles-heel/articleshow/80049872.cms>.

Chen, Jidong and Zhang, Jianquan. (2016). ‘中巴经济走廊在 “一带一路” 建设中的定位', ['The Location of Sino-Pakistan Economic Corridor in "One Belt and One Road" Construction,']《新 疆师范大学学报（哲学社会科学版）》 [Journal of Xinjiang Normal University (Philosophy and Social Sciences)] 37(4)(July): 125-33.

China Pakistan Economic Corridor, Ministry of Planning, Development and Special Initiatives, Pakistan. (2021). <http:// cpec.gov.pk>.

Chongyang Institute for Financial Studies of Renmin University. (2016). Pivot Cities on the Belt and Road (Beijing: New World Press).

Cooper, Andrew F. and Asif, B. Farooq. (2016). 'The Role of China and India in the G20 and BRICS: Commonalities or Competitive Behaviour?' Journal of Current Chinese Affairs, 45(3): 73-106.

Ethirajan, Anbarasan. (2020). 'China Debt Dogs Maldives' "Bridge to Prosperity", BBC News, 17 September, <www.bbc.com/news/world-asia-52743072>.

Findlay, Stephanie. (2020). 'Pakistan Army Muscles in on Belt and Road Project,' Financial Times, 28 August.

Findlay, Stephanie, and Farhan, Bokhari. (2021). 'Pakistan's Opposition Circles Floundering Khan,' Financial Times, 14 January.

Goldman, Russell. (2020). 'India-China Border Dispute: A Conflict Explained,' The New York Times, 17 June.

Government of Pakistan. (2020). 'CPEC Vision and Mission,' < http://cpec.gov.pk/vision-mission/3>.

The Hindu / PTI. (2020). 'Pakistan PM Imran Khan's Top Aide Steps Down Amid Corruption Allegations', 12 October, <www.thehindu.com/news/international/pakistan-pm-imran-khans-top-aide-steps-downamid-corruption-allegations/article32834854.ece>.

Hundlani, Divya and Pabasara, Kannangara. (2020). 'The Belt and Road in Sri Lanka: Beyond the Debt Trap Discussion,' The Diplomat, 7 May, < https://thediplomat.com/2020/05/the-belt-and-road-in-srilanka-beyond-the-debt-trap-discussion/>.

Hussein, Tom. (2020). 'Is China Behind Pakistan's Plan to Annex Kashmir's Gilgit-Baltistan?' South China Morning Post, 26 September, <www.scmp.com/week-asia/politics/article/3103109/chinabehind-pakistans-plan-annex-kashmirs-gilgit-baltistan>.

Jones, Lee and Shahar, Hamieri. (2020). 'Debunking the Myth of "Debt-Trap Diplomacy", Chatham House, 19 August, <www.chathamhouse.org/2020/08/debunking-myth-debt-trap-diplomacy/4-srilanka-and-bri>.

Joshi, Manoj. (2018). 'Fresh Overtures Hint at a Thaw in India-China Relations,' Asia Times, 9 March, $<$ https://asiatimes.com/2018/03/fresh-overtures-hint-thaw-india-china-relations/>.

Kalim, Inayat and Areeja, Syed. (2020). 'Maritime Economy and Gwadar Port: A Growth Catalyst,' Policy Perspectives 17(1): 73-82.

Kaplan, Robert D. (2011). Monsoon: The Indian Ocean and the Future of American Power (New York: Random House).

Kartha, Tara. (2021). 'Pak Caught in Maze of Legality Over Gilgit,' The Tribune (India), 5 January 2021, $<$ www.tribuneindia.com/news/comment/pak-caught-in-maze-of-legality-over-gilgit-193743>.

Keegan, Elmer. (2021). 'China-Pakistan Relations: Security Fence at Gwadar Port Creates New Tensions,' South China Morning Post, 2 January, <www.scmp.com/news/china/diplomacy/article/3116180/ china-pakistan-relations-security-fence-gwadar-port-creates $>$.

Khan, Hafeez-ur-Rahman. (1961). 'Pakistan's Relations with the People's Republic of China,' Pakistan Horizon 14(3): 212-32.

Khan, Naimat. (2018). 'Arab Legacy Lingers as Pakistan's Gwadar Grows from Tiny Fishing Town into Port City', Arab News, 29 April, <www.arabnews.com/node/1489531/world>.

Khetran, Mir Sherbaz. (2014). 'The Potential and Prospects of Gwadar Port', Strategic Studies 34(4): 70-89.

Kratz, Agatha, Allen, Feng, and Logan, Wright. (2019). 'New Data on the "Debt Trap" Question,' Rhodium Group, 29 April, <https://rhg.com/research/new-data-on-the-debt-trap-question/>.

Krishnan, Ananth. (2021). 'China and Pakistan Sign Military Deal Amid Tensions with India,' The Hindu, $<$ www.thehindu.com/news/international/china-and-pakistan-sign-military-deal-amid-tensionswith-india/article33219358.ece>. 
Kundi, Imran Ali. (2020). 'Second Phase of Pakistan-China Free Trade Agreement Comes into Effect,' The Nation (Pakistan), 2 January, <https://nation.com.pk/02-Jan-2020/second-phase-of-pakistanchina-free-trade-agreement-comes-into-effect $>$.

Kundi, Imran Ali. (2021). 'Pak Economy to Witness Modest 1.5 Percent Growth in FY2021: Moody's,' The Nation (Pakistan), 14January, <https://nation.com.pk/14-Jan-2021/pak-economy-to-witness-modest1-5-per-cent-growth-in-fy2021-moody-s>.

Lanteigne, Marc. (2008). 'China's Maritime Security and the "Malacca Dilemma", Asian Security 4(2): 143-61.

Lanteigne, Marc. (2019). “'The Rock that Can't be Moved": China's Revised Geostrategies in Myanmar,' Pacific Review 32(1): 37-55.

Liu, Zhongyi. (2016). ‘中巴经济走廊建设: 进展与挑战, ['Construction of the China-Pakistan Economic Corridor: Progress and Challenges'], 《国际问题研究》[International Studies] 3: 122-38.

MacDonald, Juli A., Amy, Donahue and Bethany, Danyluk. (2004). Energy Futures in Asia (McLean, VA: Booz Allen Hamilton, 2004).

Mardell, Jacob. (2020). 'The BRI in Bangladesh: Walking the Tightrope between Beijing and Delhi,' MERICS, 11 August 2020, <https://merics.org/en/analysis/bri-bangladesh-walking-tightropebetween-beijing-and-delhi>.

McDougall, Derek and Pradeep, Taneja. (2020). 'Sino-Indian Competition in the Indian Ocean Island Countries: The Scope for Small State Agency,'Journal of the Indian Ocean Region 16(2): 124-45.

Miller, Tom. (2017). China's Asian Dream (London: Zed Books).

Ministry of Foreign Affairs of the People’s Republic of China. (2021). ‘中国同巴基斯坦的关系 (最近更 新时间: 2020年4月), [Relations between China and Pakistan (Last updated: April 2020)'], January, <www.fmprc.gov.cn/web/gjhdq_676201/gj_676203/yz_676205/1206_676308/sbgx_676312/>.

Ministry of Planning, Development and Special Initiatives - Government of Pakistan. (2021). 'CPEC China-Pakistan Economic Corridor,'< <ttp://cpec.gov.pk>.

Ministry of Planning, Development and Special Initiatives - Government of Pakistan. (2020). 'Moqpondass SEZ Gilgit-Baltistan,'<http://cpec.gov.pk/project-details/67>.

Mu, Xuequan. (2018). 'China, Pakistan Vow to Push Forward All-Weather Strategic Cooperative Partnership to New High,' Xinhua, 9 August, <www.xinhuanet.com/english/2018-09/08/c_ 137454716.htm>.

Mundy, Simon and Kathrin, Hille. (2019). 'The Maldives Counts the Cost of its Debts to China,' Financial Times, 11 February.

Nyabiage, Jevans. (2021). 'China-Mauritius Free-Trade Deal Creates Model for Beijing's Trade with Africa, Observers Say,' South China Morning Post, 3 January, <www.scmp.com/news/china/diplomacy/ article/3116198/china-mauritius-free-trade-deal-creates-model-beijings-trade $>$.

Panda, Ankit. (2017). 'The Political Geography of the India-China Crisis at Doklam,' The Diplomat, 13 July, <https://thediplomat.com/2017/07/the-political-geography-of-the-india-china-crisis-atdoklam/>.

Parashar, Sachin. (2019). 'After India, Bhutan Too Likely to Skip BRI Forum,' Times of India, 14 April, $<$ https://timesofindia.indiatimes.com/world/china/after-india-bhutan-too-likely-to-skip-briforum/articleshow/68869308.cms $>$.

Peri, Dinakar, Suhasini, Haidar and Ananth, Krishnan. (2020). 'Indian Army Says 20 soldiers Killed in Clash with Chinese Troops in the Galwan Area,' The Hindu, 17 June 2020.

Reed, John. (2020). 'China and Myanmar Sign Off on Belt and Road Projects', Financial Times, 18 January. Reuters. (2016). 'Pakistani PM Welcomes First Large Chinese Shipment to Gwadar Port,' 13 November.

Reuters. (2018). 'Sri Lanka to Shift Naval Base to China-Controlled Port City', 2 July.

Reuters / South China Morning Post. (2013). 'Li Keqiang Urges Development of "China-Pakistan Economic Corridor", 23 May, <www.scmp.com/news/china/article/1244267/li-keqiang-urgesdevelopment-china-pakistan-economic-corridor>.

Robinson, J.J. (2015). The Maldives: Islamic Republic, Tropical Autocracy (London: Hurst, 2015), 88-93.

Ryack, Gene. (2020). 'A Hitch in the Belt and Road in Myanmar,' The Diplomat, 3 December, <https:// thediplomat.com/2020/12/a-hitch-in-the-belt-and-road-in-myanmar/>.

Sachdeva, Gulshan. (2018). 'Indian Perceptions of the Chinese Belt and Road Initiative,' International Studies 55(4): 285-96.

Saimum, Rubiat. (2020). 'The Prospect of Belt and Road Initiative in the Context of Bangladesh,' China Report 56(4): 464-83.

Shah, Aqil. (2020). 'Will Pakistan's Military Lose Its Grip on Power?' Foreign Affairs, 22 December, $<$ www.foreignaffairs.com/articles/pakistan/2020-12-22/will-pakistans-military-lose-its-grip-power>. 
Shah, Saeed. (2017). 'China Pushes US Aside in Pakistan,' Wall Street Journal, 18 June.

Shah, Syed H., Muhammad, A. Kamal and Da L. Yu. (2020). 'Did China-Pakistan Free Trade Agreement Promote Trade and Development in Pakistan?' International Journal of Finance and Economics (20 November) $<$ https://doi.org/10.1002/ijfe.2331>.

Shahid, Kunwar Khuldune. (2020a). 'Asim Bajwa Exposé Underlines the Corruption Linking the Pakistan Army and CPEC,' The Diplomat, 4 September, <https://thediplomat.com/2020/09/asim-bajwaexpose-underlines-the-corruption-linking-the-pakistan-army-and-cpec/>.

Shahid, Kunwar Khuldune. (2020b). 'The Unheard Voices of Kashmir,' The Diplomat, 24 December 2020, $<$ https://thediplomat.com/2020/12/the-unheard-voices-of-kashmir/>.

Shakil, F.M. (2020). 'China Slowly Retreating from Pakistan's Belt and Road', Asia Times, 26 December 2020, <https://asiatimes.com/2020/12/china-slowly-retreating-from-pakistans-belt-and-road/> .

Singh, Sushant. (2021). 'Why China Is Winning Against India,' Foreign Policy, 1 January, <https:// foreignpolicy.com/2021/01/01/india-china-himalayas-ladakh-standoff/>.

Small, Andrew. (2020). 'Returning to the Shadows: China, Pakistan, and the Fate of CPEC, German Marshall Fund of the United States - Asia Programme (16)(September).

Syed, Jawad. (2020). 'China's Belt and Road Initiative: A Pakistani Perspective,' China's Belt and Road Initiative in a Global Context - Volume II: The China-Pakistan Economic Corridor and its Implications for Business, ed. Jawad Syed and Yung-Hsiang Ying (Cham, Switzerland: Palgrave MacMillan, 2020), 13-40.

Tao, Jiyi and Gu, Heqiang. (2019). “中巴经济走廊 “早期收获” 阶段建设成效探析, ['The “Early Harvest” Phase of the China-Pakistan Economic Corridor'], 《国际论坛》 [International Forum] 3: 3-21.

Ul Hassan, Yaqoob. (2020). 'China-Pakistan Economic Corridor (CPEC) and Questions on Pakistan's Economic Stability,' Strategic Analysis 44(2): 137-52.

Vater, Tom and Laure, Siegel. (2019). 'Belt and Road Reaches Nepal's Wild North, Winning China Influence,' Nikkei Asia, 9 March, <https://asia.nikkei.com/Spotlight/Belt-and-Road/ Belt-and-Road-reaches-Nepal-s-wild-north-winning-China-influence $>$.

Veena, Ramachandran. (2018). China-Pakistan Economic Corridor: The Uyghur Challenge and the Chinese Security Model,' The Diplomat, 30 March, <https://thediplomat.com/2018/03/ chinapakistan-economic-corridor-the-uyghur-challenge-and-the-chinese-security-model/>.

Washiyama, Yumi. (2020). 'Balochi Militants Take Aim at Chinese Interests', The Diplomat, 24 July, $<$ https://thediplomat.com/2020/07/balochi-militants-take-aim-at-chinese-interests/>.

Wing, Him Yeung, Yilisha, Pang, and Asad, Aman. (2020). 'South-South Cooperation in South and East Asia: An Event Study of the China-Pakistan Economic Corridor,' Global Business Review 21(1): 54-67.

Xi, Jinping. (2014). 'Work Together to Build the Silk Road Economic Belt,' / 'Work Together to Build a $21^{\text {st }}$ Century Economic Silk Road,' The Governance of China (Beijing: Foreign Languages Press, 2014), $315-24$.

You, Hongbing and Zhou, Zhenzhen. (2019). ‘中巴经济走廊: 推动区域全面合作的新枢, ['ChinaPakistan Economic Corridor: A New Hub to Promote Regional Cooperation'], 《国际经济合作》 [International Economic Cooperation] 2: 60-9.

Zhang, Yaoming. (2019). ‘中巴经济走廊建设:成果、风险与对策,' ['Construction of the ChinaPakistan Economic Corridor: Results, Risks and Countermeasures'], 《西北大学学报 (哲学社会科 学版)》 [Journal of Northwest University (Philosophy and Social Sciences Edition)] 49(4): 14-22. 